\title{
KEEFEKTIFAN MODEL PEMBELAJARAN KOOPERATIF TIPE NUMBERED HEAD TOGETHER (NHT) TERHADAP HASIL BELAJAR MATERI SURAT PRIBADI DAN SURAT DINAS SISWA KELAS VII SMP NEGERI 2 AMBON
}

\section{Yona Witra Rumborry Grace Somelok}

Universitas Pattimura

e-mail: gracedesilo@gmail.com

\begin{abstract}
Abstrak: Model pembelajaran konvensional yang masih digunakan guru dalam pembelajaran bahasa Indonesia, pada akhirnya menempatkan guru sebagai pusat dari kegiatan pembelajaran. Hal tersebut mengakibatkan pasifnya sikap siswa dalam pembelajaran dan rendahnya hasil belajar siswa. Oleh karena itu, dibutuhkan model pembelajaran yang lebih inovatif. Salah satunya adalah model pembelajaran kooperatif tipe Numbered Head Together (NHT). Tujuan penelitian ini untuk membuktikan keefektifan model pembelajaran NHT yang dibandingkan dengan pembelajaran konvensional pada Mata Pelajaran Bahasa Indonesia, materi surat pribadi dan surat dinas. Dengan menggunakan quasi experimental design berbentuk nonequivalent control group design, hasil penelitian menunjukkan bahwa model pembelajaran NHT efektif diterapkan pada kelas eksperimen. Hal tersebut dibuktikan dengan hasil posttest kelas eksperimen yang lebih tinggi 34,63\% daripada kelas kontrol.
\end{abstract}

Kata Kunci: model pembelajaran NHT, hasil belajar 
THE EFFECTIVENESS OF COOPERATIVE LEARNING MODELS OF NUMBERED

HEAD TOGETHER (NHT) TYPE ON THE RESULTS OF LEARNING MATERIALS OF

PERSONAL LETTERS AND LETTERS OF CLASS VII STUDENTS OF JUNIOR HIGH

SCHOOL 2 AMBON

Yona Witra Rumborry

Grace Somelok

Universitas Pattimura

e-mail: gracedesilo@gmail.com

\begin{abstract}
The conventional learning model that is still used by teachers in learning Indonesian, ultimately puts the teacher as the center of learning activities. This results in passive student attitudes in learning and low student learning outcomes. Therefore, a more innovative learning model is needed. One of them is the Cooperative Numbered Head Together (NHT) type learning model. The purpose of this study was to prove the effectiveness of the NHT learning model compared to conventional learning in Indonesian Language Subjects, personal letter material and official letters. By using quasi experimental design in the form of nonequivalent control group design, the results showed that the NHT learning model was effectively applied to the experimental class. This is evidenced by the results of the experimental class posttest which was $34,63 \%$ higher than the control class.
\end{abstract}

Keywords: NHT learning model, learning outcomes 


\section{A. PENDAHULUAN}

Penerapan model pembelajaran harus sesuai dengan karakteristik siswa yang heterogen dalam suatu ruang belajar. Selain disesuaikan dengan karakteristik siswa, model pembelajaran juga harus disesuaikan dengan materi pembelajaran yang akan disampaikan. Guru mata pelajaran bahasa Indonesia pada tingkat Sekolah Menengah Pertama (SMP) dapat menerapkan model pembelajaran tertentu. Karena pada kenyataannya, proses pembelajaran yang dilakukan guru pada tingkat SMP umumnya masih belum berjalan secara maksimal. Hal ini disebabkan karena proses pembelajaran hanya berpusat pada guru yang menggunakan metode ceramah sebagai cara menyampaikan setiap materi pembelajaran. Guru kurang dapat mengaplikasikanmateri pembelajaran dalam kehidupan nyata siswa. Dilain hal siswa akan menganggap mata pelajaran bahasa Indonesia sulit untuk dipahami karena siswa kurang memahami konsep yang diberikan guru sehingga motivasi siswa untuk belajar mata pelajaran bahasa Indonesia menjadi rendah. Akibatnya hal tersebut berpengaruh terhadap hasil pencapaian belajar siswa yang kurang maksimal, termasuk pada materi surat pribadi dan surat dinas.

Materi surat pribadi dan surat dinas merupakan salah satu bagian dari materi pembelajaran bahasa Indonesia yang memerlukan konsep dan penalaran yang tepat untuk disampaikan kepada siswa. Penyampaian materi pembelajaran surat pribadi dan surat dinas dapat menggabungkan konsep tentang materi tersebut dengan pengalaman dan pengetahuan yang dimiliki siswa. Namun, di era milenial ini ketika teknologi, informasi, dan komunikasi semakin berkembang pesat, siswa kurang memahami apa itu surat. Hal tersebut disebabkan karena semakin beragamnya aplikasi pengirim pesan yang tersedia di setiap gawai yang dimiliki siswa. Pada akhirnya, siswa merasa bahwa gawai merupakan alat komunikasi yang tepat yang dapat digunakan untuk menyampaikan, menerima, dan mencari informasi dari berbagai pihak. Meskipun teknologi, informasi, dan komunikasi semakin canggih, nyatanya surat tetap menjadi alat komunikasi yang tidak dapat dihilangkan dan akan tetap digunakan.

Pada pembelajaran bahasa Indonesia materi surat pribadi dan surat dinas, penulis menawarkan salah satu model pembelajaran kooperatif. Karena dalam model pembelajaran kooperatif (cooperative learning) merupakan model pembelajaran dengan cara siswa belajar dan bekerja di dalam kelompok-kelompok kecil secara kolaboratif yang anggotanya terdiri dari empat hingga lima orang siswa dengan struktur kelompok bersifat heterogen. Konsep heterogen di sini adalah struktur kelompok yang memiliki perbedaan latar belakang kemampuan akademik, perbedaan jenis kelamin, perbedaan ras dan bahkan mungkin etnisitas. Hal ini diterapkan untuk melatih siswa menerima perbedaan dan bekerja dengan teman yang berbeda latar belakangnya (Nurdyansyah dan Fahyuni, 2016: 53).

Model pembelajaran kooperatif yang penulis tawarkan adalah model pembelajaran kooperatif tipe Numbered Head Together (NHT) untuk menumbuhkan 
motivasi siswa dalam menerima dan memahami materi yang disampaikan. Penggunaan model tersebut akan menciptakan suasana belajar yang efektif karena guru tidak hanya sebagai penceramah bagi siswa. Model pembelajaran kooperatif tipe NHT ini dapat menjadi solusi untuk permasalahan tersebut karena dengan langkah-langkah pembelajaran yang memanggil siswa secara acak sesuai nomor yang tertera pada topi yang digunakannya. Selain itu, penggunaan model pembelajaran kooperatif tipe NHT mengharapkan siswa siap dengan materi pembelajaran. Artinya, dalam pembelajaran tersebut siswa dapat menjawab pertanyaan yang diberikan oleh guru. Karena sistem model pembelajaran kooperatif tipe NHT ini, guru memanggil salah satu nomor dari setiap kelompok untuk menjawab pertanyaan yang diberikan.NHT ini juga mendorong siswa untuk meningkatkan semangat kerjasama mereka (A, Lie dalam Afandi, dkk, 2013: 65).

Walaupun pola model pembelajaran kooperatif tipe NHT berupa diskusi kelompok yang mengandalkan kerjasama antarsesama anggota kelompok, tetapi setiap siswa juga harus menyiapkan dirinya untuk memahami materi pembelajaran surat pribadi dan surat dinas yang diberikan oleh guru. Selain itu, media pembelajaran berupa contoh surat pribadi dan surat dinas juga penulis sediakan untuk lebih mempermudah siswa memahami materi pembelajaran yang disampaikan. Tujuan penelitian ini untuk mengetahui ada tidaknya pengaruh model pembelajaran kooperatif tipe NHTterhadap hasil belajar materi surat pribadi dan surat dinas siswa kelas VII. Selain itu, untuk mengetahui keefektifan penggunaan model pembelajaran kooperatif tipe NHT pada mata pelajaran bahasa Indonesia materi surat pribadi dan surat dinas.

Keberhasilan belajar siswa dapat diketahui dari hasil belajarnya. Hasil dari belajar adalah perubahan tingkah laku si subjek belajar, akan tetapi perubahan tersebut berbedabeda antarsubjek belajar. Perbedaan perubahan tingkah laku sebagai hasil dari belajar disebabkan karena berbagai faktor. Salah satu faktor yang memengaruhi keberhasilan dalam belajar yaitu faktor psikologis. Seperti yang dikemukakan Thomas F. Staton (dalam Sardiman, 2011: 39-44) terdapat enam faktor psikologis yang diperlukan dalam kegiatan belajar yaitu, motivasi, konsentrasi, reaksi, organisasi, pemahaman, dan ulangan. Menurut Sardiman (dalam Suprihatiningrum, 2016: 38) yang menyatakan dengan mengetahui hasil pekerjaan, apalagi kalau terjadi kemajuan, akan mendorong siswa untuk lebih giat belajar. Semakin mengetahui bahwa grafik hasil belajar meningkat maka ada motivasi pada diri siswa untuk terus belajar, dengan suatu harapan hasilnya terus meningkat.

Untuk meningkatkan hasil belajar siswa perlu adanya penerapan model pembelajaran yang efektif. Maka dalam penelitian ini peneliti bermaksud melakukan penelitian dengan judul "Keefektifan Model Pembelajaran Kooperatif Tipe Numbered Head Together (NHT) Terhadap Hasil Belajar Materi Surat Pribadi dan Surat Dinas Siswa Kelas VII SMP Negeri 2 Ambon." Penelitian ini dilakukan pada semester genap tahun pelajaran 2018/2019. 


\section{B. METODE PENELITIAN}

Rancangan penelitian yang digunakan yaitu penelitian eksperimen.Penelitian eksperimen diartikan sebagai sebuah studi yang objektif, sistematis, dan terkontrol untuk memprediksi dan mengontrol fenomena (Syamsudin dan Damaianti, 2007:151). Menurut Sugiyono (2018: 72) metode penelitian eksperimen merupakan metode penelitian yang digunakan untuk mencari pengaruh perlakuan tertentu terhadap yang lain dalam kondisi yang terkendalikan.Desain penelitian yang digunakan adalah quasi experimental design dengan bentuk nonequivalent control group design. Nonequivalent control group design hampir sama dengan pretest-posttest group design, hanya pada desain ini kelompok eksperimen maupun kelompok kontrol tidak dipilih secara random (Sugiyono, 2018: 79). Kelompok eksperimen diberi perlakuan yaitu penggunaan model pembelajaran kooperatif tipe NHT, sedangkan kelompok kontrol tidak diberi perlakuan dengan menggunakan model pembelajaran kooperatif tipe NHT, tetapi menggunakan pembelajaran konvensional.

Kedua kelompok ini diberi pretest dan posttest. Pretest pada kelompok eksperimen diberikan sebelum diberi perlakuan untuk mengetahui keadaan awal dan posttest diberikan setelah diberi perlakuan untuk mengetahui pengaruh perlakuan yang telah diberikan. Sedangkan, untuk kelompok kontrol yang menggunakan model pembelajaran konvensional juga diberikan pretest dan posttest. Hasil posttest pada kelas kontrol nantinya digunakan sebagai pembanding dampak perlakuan yang diberikan kepada kelompok eksperimen.

Penelitian ini dilakukan pada SMP Negeri 2 Ambon kelas VII. Populasi dalam penelitian ini adalah seluruh siswa kelas VII SMP Negeri 2 Ambon tahun pelajaran 2018/2019 yang berjumlah 281 siswa dan terbagi menjadi dua tipe rombongan belajar. Dua tipe rombongan belajar tersebut yaitu rombongan belajar kelas bilingual yang terdiri dari dua kelas dan rombongan belajar kelas reguler yang terdiri dari sembilan kelas.Sampel dalam penelitian ini menggunakan dua kelas yang dipilih secara secara acak oleh peneliti. Dua kelas tersebut yaitu kelas VII Bilingual 2 sebagai kelas eksperimen yang berjumlah 22 siswa dan kelas VII 2 sebagai kelas kontrol yang berjumlah 21 siswa. Penentuan sampel penelitian tersebut karena sampel masih berada dalam satu sekolah yang sama dan memiliki tingkat kemampuan akademik yang setara serta tidak memiliki perbedaan yang signifikan.

Variabel dalam penelitian ini terdiri dari dua variabel yaitu variabel independen (variabel bebas) dan variabel dependen (variabel terikat). Variabel bebas dalam penelitian ini yaitu model pembelajaran Numbered Head Together (NHT). Sedangkan, variabel terikat dalam penelitian ini yaitu hasil belajar materi surat pribadi dan surat dinas. Penelitian ini menggunakan beberapa instrumen penelitian, di antaranya pedoman wawancara, dokumentasi, dan tes. Berdasarkan instrumen penelitian tersebut maka teknik pengumpulan data yang digunakan antara lain, wawancara, dokumentasi, dan tes. Wawancara yang digunakan dalam penelitian ini adalah wawancara terstruktur, yang 
ditanyakan kepada guru bidang studi Bahasa Indonesia. Sedangkan dokumentasi dalam penelitian ini berupa daftar nama siswa dan foto pada saat proses pembelajaran berlangsung pada siswa kelas VII SMP Negeri 2 Ambon. Tes yang peneliti gunakan adalah tes objektif berbentuk pilihan ganda dengan empat alternatif jawaban yang berjumlah 16 butir soal dan sudah diuji validitas dan reliabilitasnya. Pengujian validitas dan reliabilitas instrumen tes menggunakan program SPSS versi 23.

\section{PEMBAHASAN}

Deskripsi data dalam penelitian ini adalah hasil tes kelas eksperimen dan kelas kontrol. Data terbagi menjadi data pretest dan data posttest yang diperoleh kedua kelas tersebut. Data pretest dan posttest siswa kelas eksperimen dan kelas kontrol disajikan pada tabel berikut ini.

Tabel Data Pretest Siswa Kelas Eksperimen dan Kelas Kontrol

\begin{tabular}{|c|l|c|c|}
\hline \multirow{2}{*}{ No. } & \multirow{2}{*}{ Kriteria Data } & \multicolumn{2}{|c|}{ Kelas } \\
\cline { 3 - 4 } & & Eksperimen & Kontrol \\
\hline 1 & Jumlah siswa & 22 & 21 \\
\hline 2 & Nilai rata-rata & 62,45 & 56,95 \\
\hline 3 & Nilai minimal & 38 & 25 \\
\hline 4 & Nilai maksimal & 88 & 81 \\
\hline 5 & Median & 63 & 63 \\
\hline 6 & Modus & 69 & 63 \\
\hline
\end{tabular}

Berdasarkan data hasil pretest siswa kelas eksperimen mendapatkan nilai ratarata 62,45 sedangkan kelas kontrol mendapatkan nilai rata-rata 56,95. Hal ini berarti nilai rata-rata pretest siswa kelas eksperimen lebih tinggi dari pada nilai rata-rata pretest kelas kontrol.

Data Posttest SiswaKelas Eksperimen dan Kelas Kontrol

\begin{tabular}{|c|l|c|c|}
\hline \multirow{2}{*}{ No. } & \multirow{2}{*}{ Kriteria Data } & \multicolumn{2}{|c|}{ Kelas } \\
\cline { 3 - 4 } & & Eksperimen & Kontrol \\
\hline 1 & Jumlah siswa & 22 & 21 \\
\hline 2 & Nilai rata-rata & 79,68 & 67,33 \\
\hline 3 & Nilai minimum & 63 & 50 \\
\hline 4 & Nilai maksimum & 100 & 81 \\
\hline 5 & Median & 81 & 69 \\
\hline 6 & Modus & 81 & 69 \\
\hline
\end{tabular}

Berdasarkan data hasil posttest siswa kelas eksperimen mendapatkan nilai ratarata 79,68 sedangkan kelas kontrol mendapatkan nilai rata-rata 67,33. Hal ini berarti 
nilai rata-rata posttest siswa kelas eksperimen lebih tinggi dari pada nilai rata-rata posttest siswa kelas kontrol.

Selain deskripsi data tersebut peneliti melakukan uji prasyarat analisis berupa uji normalitas dan uji homogenitas sebagai syarat untuk melakukan uji hipotesis. Kriteria untuk uji normalitas yaitu apabila nilai signifikansi $>0,05$ maka data berdistribusi normal, tetapi jika nilai signifikansi $<0,05$ maka data tidak berdistribusi normal (Priyatno, 2017: 91). Sedangkan, kriteria untuk pengambilan keputusan untuk uji homogenitas yaitu jika nilai signifikansi $>0,05$ maka data tersebut sama atau homogen, tetapi jika nilai signifikansi $<0,05$ maka data tersebut tidak sama atau tidak homogen (Priyatno, 2017: 101). Uji prasyarat analisis tersebut menggunakan program SPSS versi 23. Hasil pengujian untuk uji normalitas didapatkan nilai signifikansi pretest kelas eksperimen lebih dari $0,05(0,200>0,05)$, posttest kelas eksperimen lebih dari 0,05 $(0,200>0,05)$, pretest kelas kontrol lebih dari $0,05(0,128>0,05)$, dan posttest kelas kontrol lebih dari $0,05(0,062>0,05)$. Dari data tersebut maka dapat dikatakan bahwa data pretest-posttest kelas eksperimen dan data pretest-posttest kelas kontrol berdistribusi normal karena keempat data tersebut menunjukkan nilai signifikansi lebih dari 0,05 .

Selain itu, hasil uji homogenitas didapatkan nilai signifikansi lebih dari 0,05 atau 0,929>0,05. Dari data tersebut maka dapat dikatakan bahwa data hasil belajar siswa pada kelas eksperimen dan kelas kontrol homogen atau sama karena menunjukkan nilai signifikansi lebih dari 0,05. Maka berdasarkan uji prasyarat analisis tersebut diketahui bahwa data penelitian bersifat normal dan homogen. Selanjutnya, dapat dilakukan uji hipotesis yang berupa uji independent samples t test dan uji one samples t test masih dengan menggunakan program SPSS versi 23. Uji independentsamples t testdilakukan untuk mengetahui perbedaan dua sampel yang tidak berpasangan atau independen. Pada pengujian ini digunakan nilai posttest siswa pada kelas eksperimen dan kelas kontrol. Kriteria untuk pengambilan keputusan uji independent samples $t$ test adalah jika nilai signifikansi $>0,05$ maka Hol diterima, tetap jika nilai signifikansi $<0,05$ maka Ho1 ditolak atau -ttabel $>$-thitung atau thitung $<$ ttabel maka Hol diterima, tetapi jika thitung $<-$ ttabel atau thitung $>$ ttabel maka Hol ditolak (Priyatno, 2017: 201). Berikut ini hipotesis statistik pengujian independent samples $t$ test.

Ho1 : Tidak ada pengaruh model pembelajaran kooperatif tipe NHT materi terhadap hasil belajar materi surat pribadi dan surat dinas.

Hal : Ada pengaruh model pembelajaran kooperatif tipe NHT materi terhadap hasil belajar materi surat pribadi dan surat dinas.

Berdasarkan data penelitian didapatkan nilai signifikansi 0,000 . Hal ini berarti nilai signifikansi tersebut kurang dari $0,05(0,000<0,05)$. Penelitian ini menggunakan 43 sampel yang terdiri dari 22 sampel pada kelas eksperimen dan 21 sampel pada kelas kontrol. Dari 43 sampel (n) tersebut kemudian dihitung nilai derajat kebebasan $(\mathrm{df})=\mathrm{n}$ $-2=43-2=41$ dengan taraf kesalahan 5\%. Selanjutnya, digunakan uji 2 sisi, maka diketahui nilai ttabel untuk df 41 sebesar 2,020. Karena data penelitian homogen yang digunakan adalah equal variances assumed dengan thitung sebesar 3,966. 
Penghitungan tersebut menunjukkan bahwa nilai thitung $>$ ttabel yaitu 3,966> 2,020. Nilai signifikansinya lebih kecil dari 0,05 atau $0,000<0,05$. Berdasarkan penghitungan menggunakan program SPSS versi 23 dapat dikatakan bahwa Ho1 ditolak dan Hal diterima. Jadi, dapat disimpulkan bahwa ada pengaruh model pembelajaran kooperatif tipe NHT terhadap hasil belajar materi surat pribadi dan surat dinas siswa kelas VII.

Selain uji independent samples t test peneliti juga melakukan pengujian lain yang berupa uji one samples t test menggunakan program SPSS versi 23. Pengujian ini merupakan uji hipotesis untuk mengetahui keefektifan model pembelajaran kooperatif tipe NHT menggunakan data hasil posttest siswa pada kelas eksperimen. Kriteria pengambilan keputusan untuk pengujian ini jika nilai signifikansi $>0,05$ atau thitung $\leq$ ttabel Ho2 diterima, tetapi jika nilai signifikansi $<0,05$ atau -ttabel $>$ thitung atau thitung $>$ ttabel maka Ho2 ditolak (Siregar, 2017: 165). Hipotesis statistik untuk uji one samples t test adalah sebagai berikut.

Ho2 : Penggunaan model pembelajaran kooperatif tipe NHT tidak efektif diterapkan pada mata pelajaran bahasa Indonesia materi surat pribadi dan surat dinas.

Ha2 : Penggunaan model pembelajaran kooperatif tipe NHT efektif diterapkan pada mata pelajaran bahasa Indonesia materi surat pribadi dan surat dinas.

Berdasarkan data penelitian didapatkan nilai signifikansi sebesar 0,000. Maka nilai signifikansi tersebut kurang dari $0,05(0,000<0,05)$. Nilai ttabel untuk df 21 yaitu 1,721 , sedangkan thitung 36,608. Berdasarkan penghitungan tersebut maka diketahui bahwa thitung $>$ ttabel atau 36,608 $>1,721$, maka Ho2 ditolak dan Ha2 diterima. Jadi, dapat disimpulkan bahwa penggunaan model pembelajaran kooperatif tipe NHT efektif diterapkan pada mata pelajaran bahasa Indonesia materi surat pribadi dan surat dinas.

Setelah dilakukan pengujian hipotesis yang berupa uji independent samples $t$ test dan uji one samples $t$ test, peneliti menggunakan cara lain untuk menguji keefektifan mode pembelajaran NHT pada materi surat pribadi dan surat dinas. Cara yang peneliti gunakan adalah membandingkan hasil nilai pretest-posttest siswa kelas eksperimen dengan hasil pretest-posttest siswa kelas kontrol. Perbandingan nilai posttest kedua kelas tersebut didasarkan pada standar KKM mata pelajaran bahasa Indonesia sebesar 70.Untuk menentukan keefektifan suatu proses pembelajaran adalah apabila hasil belajar siswa telah memenuhi KKM individual yang telah ditetapkan, yaitu sebesar 70 . Jadi, siswa dikatakan tuntas apabila mendapatkan nilai posttest lebih dari atau sama dengan 70.

Berikut ini tabel nilai posttest kelas eksperimen dan kelas kelas kontrol berdasarkan standar KKM. 
Tabel Nilai Posttest Kelas Eksperimen Berdasarkan Nilai Kriteria Ketuntasan Minimal (KKM)

\begin{tabular}{|c|c|c|}
\hline \multirow{2}{*}{ No. } & \multicolumn{2}{|c|}{ Kelas Eksperimen } \\
\hline & Posttest & Kriteria \\
\hline 1 & 94 & tuntas \\
\hline 2 & 81 & tuntas \\
\hline 3 & 94 & tuntas \\
\hline 4 & 69 & tidak tuntas \\
\hline 5 & 75 & tuntas \\
\hline 6 & 81 & tuntas \\
\hline 7 & 81 & tuntas \\
\hline 8 & 88 & tuntas \\
\hline 9 & 75 & tuntas \\
\hline 10 & 81 & tuntas \\
\hline 11 & 75 & tuntas \\
\hline 12 & 69 & tidak tuntas \\
\hline 13 & 63 & tidak tuntas \\
\hline 14 & 100 & tuntas \\
\hline 15 & 88 & tuntas \\
\hline 16 & 69 & tidak tuntas \\
\hline 17 & 88 & tuntas \\
\hline 18 & 63 & tidak tuntas \\
\hline 19 & 69 & tidak tuntas \\
\hline 20 & 88 & tuntas \\
\hline 21 & 81 & tuntas \\
\hline 22 & 81 & tuntas \\
\hline \multirow{2}{*}{ Jumlah } & Tuntas & 16 \\
\hline & tidak tuntas & 6 \\
\hline \multirow{2}{*}{ Persentase } & Tuntas & $72,73 \%$ \\
\hline & tidak tuntas & $27,27 \%$ \\
\hline
\end{tabular}

Berdasarkan tabel tersebut dapat diketahui bahwa pada kelas eksperimen terdapat 16 siswa yang memperoleh nilai posttest $>70$ atau melebihi standar KKM (tuntas) dan 6 siswa yang memperoleh nilai posttest $<70$ atau tidak mencapai standar KKM (tidak tuntas). Apabila data posttest kelas eksperimen tersebut dipersentasekan maka diperoleh hasil posttest siswa yang tuntas pada kelas eksperimen yaitu 72,73\% dan $27,27 \%$ siswa yang tidak tuntas. 
Tabel Nilai Posttest Kelas Kontrol

Berdasarkan Nilai Kriteria Ketuntasan Minimal (KKM)

\begin{tabular}{|c|c|c|}
\hline \multirow{2}{*}{ No. } & \multicolumn{2}{|c|}{ Kelas Kontrol } \\
\cline { 2 - 3 } & Posttest & Kriteria \\
\hline 1 & 69 & tidak tuntas \\
\hline 2 & 81 & Tuntas \\
\hline 3 & 81 & Tuntas \\
\hline 4 & 75 & Tuntas \\
\hline 5 & 75 & Tuntas \\
\hline 6 & 69 & tidak tuntas \\
\hline 7 & 81 & Tuntas \\
\hline 8 & 63 & tidak tuntas \\
\hline 9 & 75 & Tuntas \\
\hline 10 & 56 & tidak tuntas \\
\hline 11 & 56 & tidak tuntas \\
\hline 12 & 75 & Tuntas \\
\hline 13 & 63 & tidak tuntas \\
\hline 14 & 69 & tidak tuntas \\
\hline 15 & 63 & tidak tuntas \\
\hline 16 & 75 & Tuntas \\
\hline 17 & 69 & tidak tuntas \\
\hline 18 & 50 & tidak tuntas \\
\hline 19 & 69 & tidak tuntas \\
\hline 20 & 50 & tidak tuntas \\
\hline 21 & 50 & tidak tuntas \\
\hline \multirow{2}{*}{ Jumlah } & tuntas & 8 \\
\cline { 2 - 3 } Persentase & tidak tuntas & 13 \\
\cline { 2 - 3 } & tidak tuntas & $61,90 \%$ \\
\hline
\end{tabular}

Pada tabel 4.13 data posttest kelas kontrol menunjukkan bahwa terdapat 8 siswa yang memperoleh nilai posttest $>70$ atau melebihi standar KKM (tuntas) dan 13 siswa yang memperoleh nilai posttest $<70$ atau tidak mencapai standar KKM (tidak tuntas). Namun, jika data posttest pada kelas kontrol dipersentasekan maka diperoleh hasil posttest siswa yang tuntas yaitu $38,1 \%$, sedangkan $61,90 \%$ menunjukkan persentase siswa yang tidak tuntas.

Dengan demikian jumlah siswa pada kelas eksperimen lebih banyak yang memperoleh nilai posttest $>70$ dibandingkan kelas kontrol. Selain itu, persentase nilai posttest kelas eksperimen lebih tinggi 34,63\% jika dibandingkan persentase nilai posttest kelas kontrol. Hasil posttest kelas eksperimen yang lebih tinggi dari pada kelas kontrol ini disebabkan adanya perlakuan yang diterapkan pada kedua kelas tersebut. Kelas eksperimen yang mendapat perlakuan berupa model pembelajaran kooperatif tipe NHT dan kelas kontrol menggunakan model pembelajaran konvensional. Jadi, dapat 
disimpulkan bahwa model pembelajaran kooperatif tipe NHT sangat efektif diterapkan pada mata pelajaran bahasa Indonesia materi surat pribadi dan surat dinas.

\section{KESIMPULAN}

Data hasil penelitian menunjukkan model pembelajaran kooperatif tipe NHT efektif diterapkan pada materi surat pribadi dan surat dinas dan berpengaruh pada hasil belajar siswa. Hal ini dibuktikan pada kelas eksperimen memiliki nilai rata-rata pretest 62,45 dan nilai rata-rata posttest 79,68 . Pada kelas kontrol memiliki nilai rata-rata pretest 56,95 dan nilai rata-rata posttest 67,33. Dari hasil tersebut dapat dilihat bahwa perbedaan nilai kedua kelas tersebut, nilai yang didapatkan siswa di kelas eksperimen lebih tinggi dari pada yang didapatkan siswa di kelas kontrol.

Dua kelas tersebut sama-sama mendapatkan materi pembelajaran surat pribadi dan surat dinas dengan alokasi waktu yang sama. Hanya saja kelas kontrol menggunakan model pembelajaran konvensional, sedangkan kelas eksperimen menggunakan model pembelajaran kooperatif tipe NHT. Penggunaan model pembelajaran yang berbeda itulah yang menyebabkan siswa di kelas eksperimen memiliki nilai posttest lebih tinggi dibanding nilai posttest di kelas kontrol. Nilai rata-rata posttest kelas eksperimen sebesar 79,68 dan kelas kontrol sebesar 67,33. Ini berarti terdapat selisih sebesar 12,35 pada nilai rata-rata posttest kedua kelas tersebut.

Selain itu, terdapat perbedaan antara hasil belajar kelas eksperimen yang menggunakan model pembelajaran kooperatif tipe NHT dengan kelas kontrol yang menggunakan model pembelajaran konvensional. Hal tersebut dibuktikan dengan output SPSS versi 23 ujiindependent samples t test yang menghasilkan nilai thitung $>$ ttabel yaitu 3,966 $>2,020$. Nilai signifikansinya lebih kecil dari 0,05 atau $0,000<0,05$. Model pembelajaran kooperatif tipe NHT efektif diterapkan pada kelas eksperimen karena hasil posttest setelah perlakuan yang berupa penerapan model pembelajaran kooperatif tipe NHT lebih besar dari pada hasil pretest sebelum perlakuan. Selain itu, output SPSS versi 23 uji one samples t test menghasilkan nilai signifikansi 0,000 yang kurang dari $0,05(0,000<0,05)$. Nilai ttabel untuk df 21 yaitu 1,721, sedangkan thitung 36,608. Penghitungan tersebut menunjukkan bahwa thitung $>$ ttabel atau 36,608 $>1,721$. Berdasarkan penghitungan hasil peneltitan tersebut maka dapat disimpulkan bahwa model pembelajaran NHT efektif diterapkan pada materi surat pribadi dan surat dinas siswa kelas VII SMP Negeri 2 Ambon. 


\section{DAFTAR PUSTAKA}

Afandi, Muhammad. dkk. 2013. Model dan Metode Pembelajaran di Sekolah. Semarang: Unissula Press.

M, Sardiman A. 2011. Interaksi dan Motivasi Belajar Mengajar. Jakarta: Rajawali Pers.

Nurdyansyah dan Eni Fariyatul Fahyuni. 2016. Inovasi Model Pembelajaran Sesuai Kurikulum 2013. Sidoarjo: Nizamia Learning Center.

Priyatno, Duwi. 2017. Panduan Praktis Olah Data Menggunakan SPSS. Yogyakarta: Andi.

Siregar, Syofian. 2017. Metode Penelitian Kuantitatif Dilengkapi dengan Perbandingan Perhitungan Manual \& SPSS. Jakarta: Kencana.

Sugiyono. 2018. Metode Penelitian Kuantitatif, Kualitatif, dan R\&D. Bandung: Alfabeta.

Suprihatiningrum, Jamil. 2016. Strategi Pembelajaran: Teori dan Aplikasi. Yogyakarta: Ar-Ruzz Media. 